\title{
赤外線放射温度計による表面欠皕の検出*
}

\author{
岡 本 芳三*1, 神 永文 人 $^{* 1}$, 刑 部 真 弘 $^{* 1}$ \\ 大 岡 紀 一*2, 小川和 彦*3, 金谷邦 雄*2
}

\section{Surface Crack Detection by Infrared Radiometer}

\author{
Yoshizo OKAMOTO, Fumito KAMINAGA, Masahiro OSAKABE, \\ Kiichi OHOKA, Kazuhiko OGAWA, and Kunio KANAYA
}

\begin{abstract}
Surface cracks can be detected by using an infrared radiation sensor. In the present study, a surface crack detection method by using the infrared radiometer was applied to a test plate with artificial cracks. The cracks could be detected with the higher equivalent radiation temperature at the crack than that of the flat surface. The minimum crack, $40 \mu \mathrm{m}$ in width and $10 \mu \mathrm{m}$ in depth, could be detected by using the present infrared radiation sensor.
\end{abstract}

Key Words: Materials Surface Crack, Non-destructive Test, Remote-sensing, Cavity Radiation, Slit Crack, Pinhole

\section{1. 緒}

物体表面より放出される赤外線放射エネルギーを非 接触でとらえ，二次元のサーモ像として表示する，い わゆる赤外線りモートセンシング技術は, 医学, 気象, 土木などの分野で広く利用されている(1). 一方, 工業 材料表面に発生するピンホール，割れや傷などの欠陥 を検出する方法としては, 浸透法, 磁粉探傷法, X線 透過，超音波などの実用化された手法が，非破壊検查. 法として適用されている,さらに現在, 原子力や高温 プラント等におけるように, 人間が近づきにくい機器 や構造物などの表面に発生または存在する表面欠陥を 非接触または遠隔で検出する非破壊検查法として, 新 たなりモートセンシング技術の開発が積極的に進めら れている。このような点に着目し, 著者らは表面に存 在する欠陥より放出される放射エネルギーを赤外線セ ンサで検出し，周辺表面に比べて欠陥部での放射温度 の増分が欠陥画像の検出に有効であることを報告し た ${ }^{(2)}$.

\footnotetext{
* 昭和 63 年 5 月 31 日 第 7 回「センサーの基整と応用」シン ポジウムにおいて講演, 原稿受付 昭和 63 年 10 月 3 日.

*1 正員, 茨城大学工学部(更316 日立市中成沢町 4-12-1).

*2 正員, 日本原子力研究所 (画311-13 茨城県東茨城郡大洗町).

*3 学生員, 茨城大学工学部.
}

本報では，表面欠陌として線（く形断面）状の割れ， $\mathrm{V}$ 形の傷および円柱状ピンホールを対象として, 赤外 線センサによるサーモ像を求め, 欠陥の検出を行っ た。試料温度を増加し, 放射熱流束を增やすことによ り, 久陥の映像の鮮明化と検出感度を向上させるのに 有効であることを明らかにした。

記 号

$$
\begin{aligned}
& a: \text { 射出率 } \\
& b: \text { 次陌の幅 } \\
& d: \text { 次陥の直径 } \\
& h: \text { 次宿の深さ } \\
& J: \text { 放射熱流束 } \\
& T: \text { 温度 }
\end{aligned}
$$

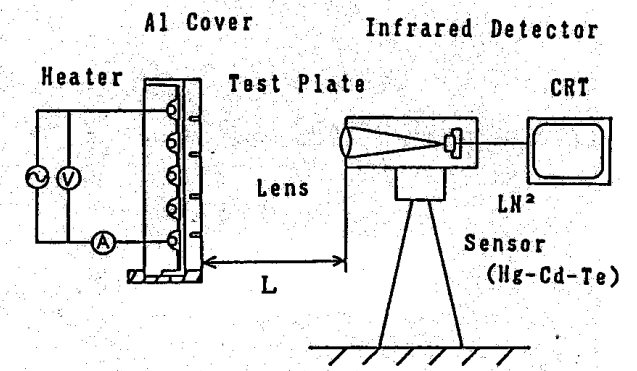

図 1 実験装置概略 
1320

$$
\begin{aligned}
& T^{\prime}: \text { 等価放射温度 } \\
& \rho: \text { 反射率 } \\
& \text { 添 } \\
& s: \text { 表面 }(\text { 平面 }) \\
& c: \text { 欠陌 } \\
& b: \text { 黒体 }
\end{aligned}
$$

\section{2. 試験装置と方法}

図 1 は，実験装置の概念図を示す。人工欠陥付きの 試験片を, 電気加熱板に取付け, 距離 $L$ 離れた赤外線 放射温度計によって, 試験片の温度分布を CRT 上に 表示する. 試験片の材質は, ステンレス, 黄銅, アルミ ニウムおよびグラファイトである.また，V形および ピンホールの人工欠陥を, フライスまたは放電加工に より, 平滑面上に取付けた.試験片の温度は, 試験片の 側面より埋め込まれた熱電対により計測した。試料表 面には基準となる黒体面 (b)が黒色ペンキで取付けら れている。

本研究に用いた赤外線温度計では, 液体窒素により 冷却された $\mathrm{Hg}-\mathrm{Cd}-\mathrm{Te}$ センサを用いている. 赤外線 温度計の主な仕様は, 以下である。

検出波長帯 : 8 $13 \mu \mathrm{m}$

計測温度範囲 : $-50 \sim 1200^{\circ} \mathrm{C}$

計測誤差 : $0.1 \sim 70^{\circ} \mathrm{C}$

焦点距離 : $15 \mathrm{~cm} \sim \infty$

また，得られる放射温度は，試料面上の一辺 $b_{m}$ の四 角形の面積平均として表示される。 $b_{m}$ は，検出器から の距離 $15 \mathrm{~cm}$ の試料において, $0.5 \mathrm{~mm}$ である.

実験は，試料を加熱および非加熱の条件で行った。 定常状態において, 欠陥中心の放射温度 $T_{c}^{\prime}$, 欠陥周辺 表面の放射温度 $T_{s}^{\prime}$, および黑色ペンキを塗った表面の 放射温度 $T_{b}^{\prime}$,を, 赤外線放射温度計によって, 計測し た。

試料表面 $(s)$, 欠陥 $(c)$ および試料表面の基準となる

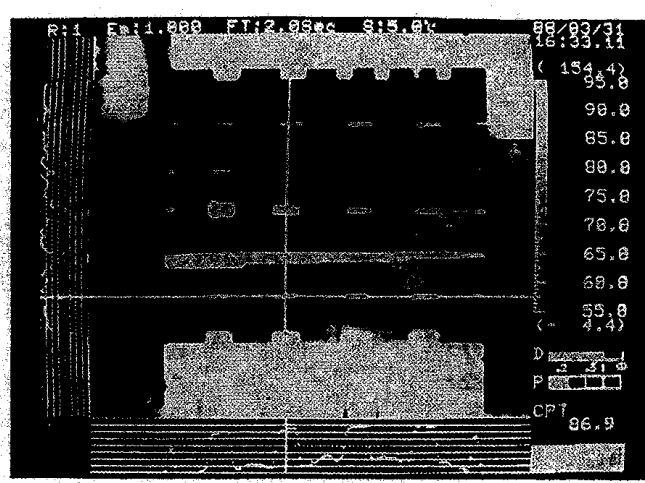

図 2 ステンレス鋼試験片のサーモ像
黒体面 (b) より低温の黑体とみなせる赤外センサに入 射される検出波長範囲 $(8 \sim 13 \mu \mathrm{m})$ の放射熱流束 $J_{s}$, $J_{c}, J_{b}$ は，近似的に式(1)，（2）（3）で表される。

$$
\begin{aligned}
& J_{s}=\sigma \varepsilon_{s} T_{w}^{4}+\sigma \rho_{s} T_{a}^{4} \\
& J_{c}=\sigma \varepsilon_{c} T_{w}^{4}+\sigma \rho_{c} T_{a}^{4} \\
& J_{b}=\sigma \varepsilon_{b} T_{w}^{4}
\end{aligned}
$$

ここで， $T_{w}, T_{a}$ は試料および試料をとりまく周辺 の温度, $\varepsilon, \rho$ は試料各部の放射率および反射率， $\sigma$ は 常数である.ここで, 式(1)〜（3）において，灰色近似 により, $\rho=1-\varepsilon$ とすると, 赤外線温度計の画像上の ( $s),(c),(b)$ の温度 $T_{b}^{\prime}, T_{s}^{\prime}, T_{c}^{\prime}$ はそれぞれ式(4)， (5)，（6）で表される.

$$
\begin{aligned}
J_{s} & =\sigma \varepsilon_{s} T_{w}^{4}+\sigma\left(1-\varepsilon_{s}\right) T_{a}^{4} \\
& =\sigma a_{s} T_{w}^{4}=\sigma T_{s}^{\prime 4} \ldots \ldots \ldots \ldots \\
J_{c} & =\sigma \varepsilon_{c} T_{w}^{4}+\sigma\left(1-\varepsilon_{c}\right) T_{a}^{4} \\
& =\sigma a_{c} T_{w}^{4}=\sigma T_{c}^{4} \ldots \ldots \ldots . \\
J_{b} & =\sigma \varepsilon_{b} T_{w}^{4}=\sigma T_{b}^{\prime 4} \ldots \ldots \ldots . .
\end{aligned}
$$

ここで $a$ は試料各部の反射を考慮にいれた放射率, $T^{\prime}$ は見かけの放射温度を示す.いま, 式(4)，(5)で, $T_{w}=T_{a}$ である場合を考えると， $a_{s}=a_{c}=1$ であり， 欠陷部と表面での放射温度差がなくなり，欠陥の検出 ができなくなることを示している， $T_{w} \gg T_{a}$ では，反 射の影響が小さくなり， $a_{s}$ と $a_{c}$ の差が検出できる.

計測した $T_{s}^{\prime}$ と $a_{s}$ は，表面の污れ，酸化の程度およ び表面粗さ等によって影響される.使用した材料の $T_{s}^{\prime}$ と $a_{s}$ の標準偏差の一例を以下に示す.

$$
\begin{array}{ll}
\text { ステンレス }: & T_{s}^{\prime}=34.5 \pm 2.4 \\
& a_{s}=0.69 \pm 0.02 \\
\text { 黄銅 }: & T_{s}^{\prime}=35.2 \pm 1.8 \\
\text { アルミニウム } & a_{s}=0.53 \pm 0.1 \\
& T_{s}^{\prime}=36.6 \pm 0.9 \\
a_{s} & =0.26 \pm 0.004
\end{array}
$$

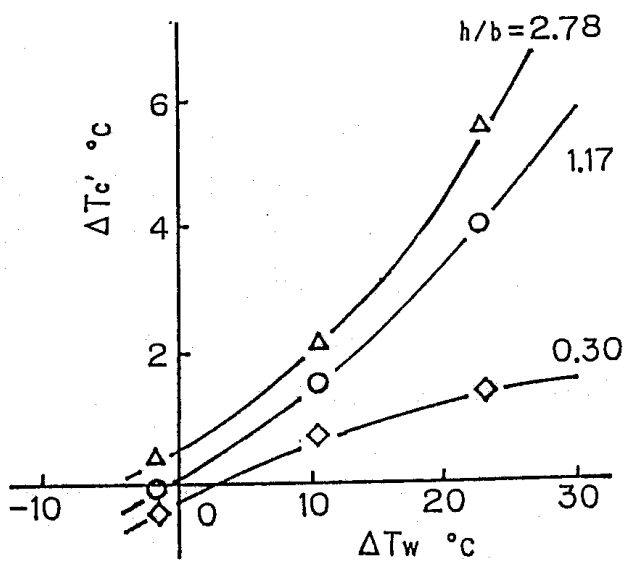

図 $3 h / b$ をパラメータとしたときの $\Delta T_{w}$ と $\Delta T_{c}^{\prime}$ の関倸 


$$
\text { グラファイト } \begin{aligned}
T_{s}^{\prime} & =32.0 \pm 0.3 \\
a_{s} & =0.92 \pm 0.004
\end{aligned}
$$

このような,バラツキを避けるため従来法では, 表面 を黒色ペンキで塗っていたが, 欠陥がペイント膜によ って，覆われてしまうために，適切な方法とは言えな い(3). 本研究では，表面の放射温度 $T_{s}^{\prime}$ は，欠陥の周囲 の平均温度より求め, 欠陷における最大温度を $T_{c}^{\prime}$ と した.

\section{3. 実 験 結 果}

$3 \cdot 1$ 線状欠陥の特性 ステンレス鋼, 黄銅の試 験片の表面に, 長さ $10 \mathrm{~mm}$, 幅 $5 \sim 0.15 \mathrm{~mm}$, 深さ $4 \sim 0.3 \mathrm{~mm}$ の線状欠宿を取付けた.

図 2 は, ステンレス試料の線状欠陥部の放射温度画 像を示す.下および左側の各図は, 写真のカーソル線 上の久俩の温度分布を示したものである. 久陷断面内 の温度分布は, 中心部で最大値をもつ山形の温度分布 をもっていることがわかる，上下の水平方向の白い帯 状の部分は, 放射の基準となる黒色ペンキを塗布した 黒体部分を示している.

図 3 は欠陥の深さと幅の比 $h / b$ をパラメータとし て, 室温と黄銅試験片との温度差 $\left(\Delta T_{w}=T_{w}-T_{a}\right)$ と 欠陥とその周囲との温度差 $\left(\Delta T_{c}^{\prime}=T_{c}^{\prime}-T_{s}^{\prime}\right)$ の関係を 示したものである， $h / b$ の值が大きいほど, $\Delta T_{c}^{\prime}$ は増 加する.すなわち，㐸俩のサーモ像は，試験片を加熱す ることによって，鮮明になることを示している．

図 4 は, $\Delta T_{w}$ をパラメータとして, $h / b$ と $\Delta T_{c}^{\prime}$ の 関係を示したものである. $\Delta T_{w}$ および $h / b$ が大きいほ

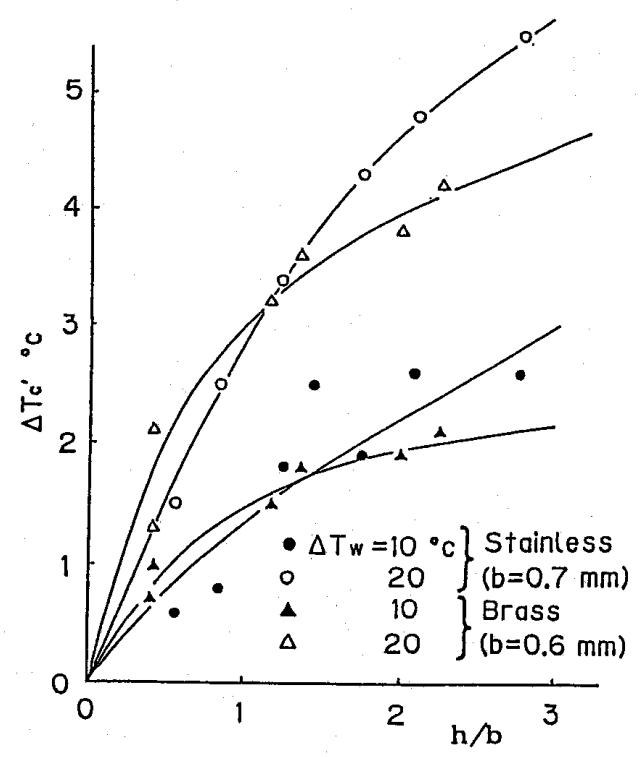

図 $4 \Delta T_{w}$ をパラメータとしたときの $\Delta T_{c}^{\prime}$ と $h / b$ の関係
ど, $\Delta T_{c}^{\prime}$ が増加する. $\Delta T_{w}=10^{\circ} \mathrm{C}$ における計測デー夕 のばらつきは, 反射の影響によると考えられる. $\Delta T_{w}$ が $20^{\circ} \mathrm{C}$ になると、そのばらつきは小さくなった。

図 5 は, $\Delta T_{w}$ をパラメー夕として, $a_{c}$ と $h / b$ の関 係を表したものである。 h/bの増加とともに， $a_{c}$ は大 きくなり，1.0に近づく.

線状欠陥の内部表面の射度が，一様であると考えら れるとき, 空洞放射率 $\varepsilon_{c}$ は(4), $^{(4)}$

$$
\varepsilon_{c}=\frac{\varepsilon_{s}}{\varepsilon_{s}+b\left(1-\varepsilon_{s}\right) /(2 h+b)}
$$

図 5 に示した一点鎖線は, 式 ( 5 ) と式 (7) を使って 得られた計算結果である。実験および計算とも， $h / b$ が大きくなるにつれ， $a_{c}$ が増大していることがわか る. すなわち, 放射温度計の検出波長 $(8 \sim 13 \mu \mathrm{m})$ に比 べて, 比較的大きなサイズの欠陥では, 欠宿部での放 射温度の増分は，空洞放射効果によると考えられる。

図 6 は,グラファイトの場合に $\Delta T_{w}$ をパラメータ

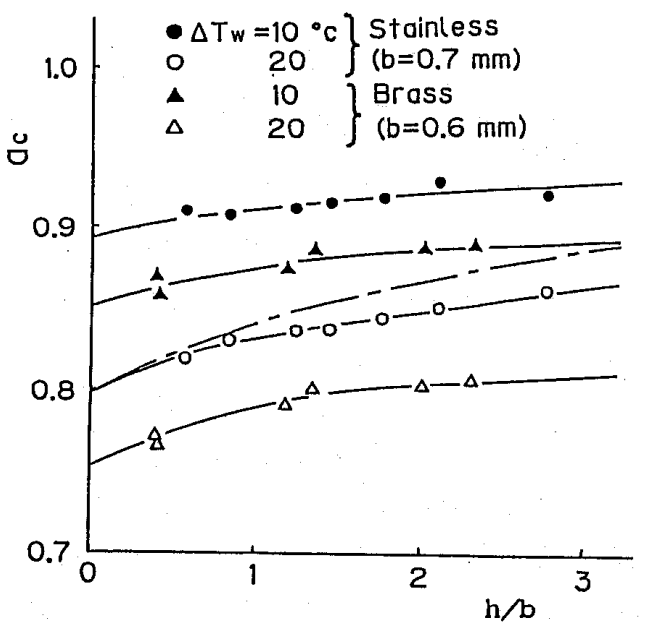

図 $5 \Delta T_{w}$ をパラメータとしたときの $a_{c}$ と $h / b$ の関係

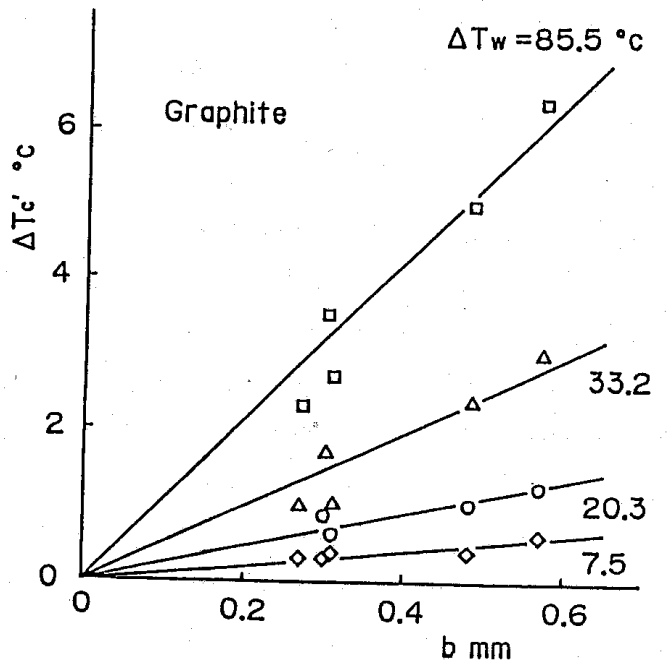

図 $6 \Delta T_{w}$ をパラメータとしたときの $\Delta T_{c}^{\prime}$ と $b$ の関係 


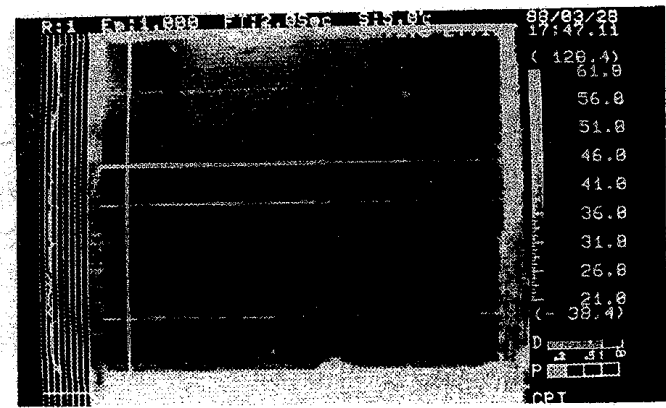

図 7 アルミニウム試験片のサーモ像

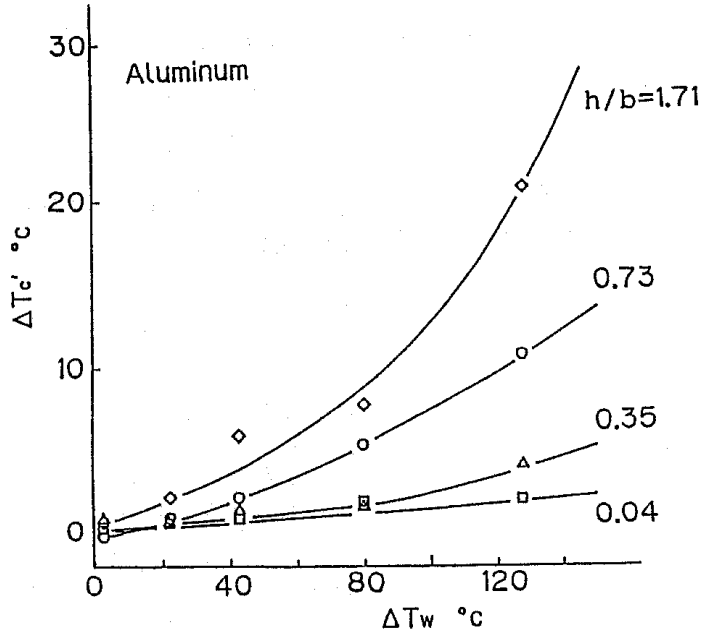

図 $8 h / b$ をパラメータとしたときの $\Delta T_{w}$ と $\Delta T_{c}^{\prime}$ の関係

として欠楩の幅 $b$ と $\Delta T_{c}^{\prime}$ の関係を表したものであ る. $a_{c}$ は, 試料面が周囲温度に比べて高いときには, 1.0 を越えることはない.したがって,グラファイトの $a_{s}$ が 0.98 と黒体に近いことから，欠陥を検出するこ とは，難しい，しかし， $\Delta T_{w}$ を大きくすることによっ て, $0.3 \mathrm{~mm}$ 幅の欠陥を検出することが可能であっ た.

X線および超普波を使って, 検出できる最小の欠陥 幅は, $0.1 \sim 0.3 \mathrm{~mm}^{(2)}$ であることから, 本研究の赤外 線放射温度計による方法は，欠陷検出のために有用な 方法であると考えられる。

$3 \cdot 2$ V 形線状欠陥 $3 \cdot 1$ 節より小さい線状欠陥 を検出することが，可能かどうか検討するために，最 小 $40 \mu \mathrm{m}$ 幅で $10 \mu \mathrm{m}$ 深さのV形の傷をアルミニウム 試験片の上に製作した，図 7 に示したのは，試験片の 放射温度像である。赤外線温度計の検出波長程度の深 さをもつ欠楩においても，周囲表面に比べたときの欠 陥での温度増加が, 得られた像に見られた。図 8 は, $h / b$ をパラメータとした時の, $\Delta T_{w}$ と $\Delta T_{c}^{\prime}$ の関係で ある. $\Delta T_{w}$ と $h / b$ が大きいほど, 大きな $\Delta T_{c}^{\prime}$ が得ら れている. 図 9 は, $\Delta T_{w}$ をパラメータとして, $a_{c}$ と

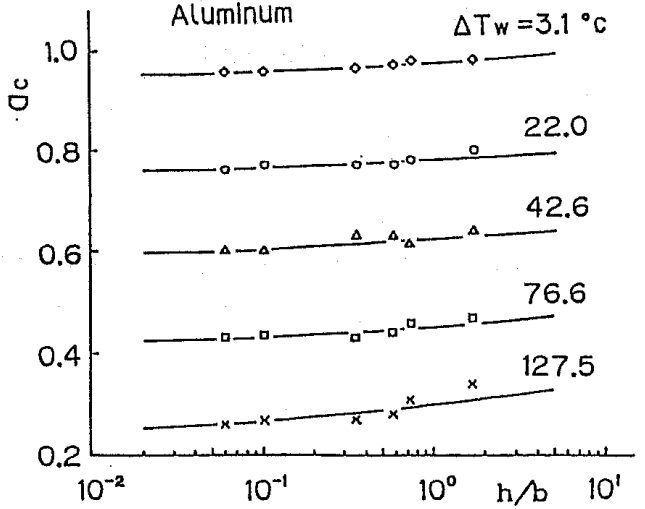

図 $9 \Delta T_{w}$ をパラメータとしたときの $a_{c}$ と $h / b$ の関係

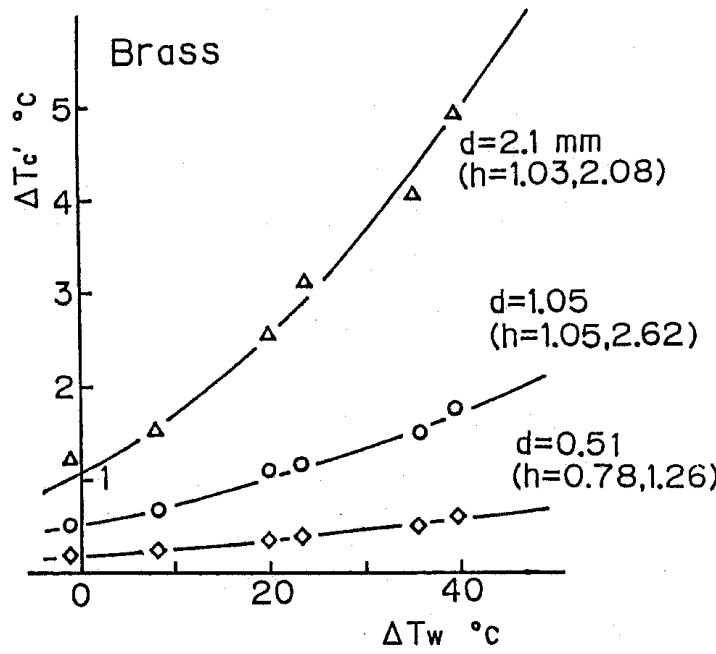

図 10 ピシホールの直径 $d$ をパラメータとしたときの $\Delta T_{w}$ と $\Delta T_{c}^{\prime}$ の関係

$h / b$ の関係を表したものである. $a_{c}$ の值は, $h / b$ の值 とともに緩やかに増加する。

$3 \cdot 3$ ピンホールの特性 人工的なピンホールを 黄銅表面に作った。図 10 に示したのは, ピンホールの 直径をパラメータとして, $\Delta T_{w}$ と $\Delta T_{c}^{\prime}$ の関係を表し たものである. $\Delta T_{c}^{\prime}$ の值は, 線状欠陥の場合に比べて, 比較的小さい、 $\Delta T_{w}$ を大きくすれば, 直径 $0.5 \mathrm{~mm} の$ 欠陥の検出が可能であった。

\section{4. 結論}

（1）赤外線放射計を用いて，線状，V形およびピ ンホールの表面欠陥を検出することができた，検出は， 表面に比べたときの欠陥部での高い放射温度による。

（2）試料を加熱することにより，放射温度差 $\Delta T_{c}^{\prime}$ が増加し，より鮮明な欠陥像を得た。

（3）最小の久陥として, 幅 $40 \mu \mathrm{m}$, 深さ $10 \mu \mathrm{m}$ の 欠陷が赤外線放射計によって検出可能であった。

本研究は, 東京大学原子力工学施設の共同利用研究 
の一貫として実施したものである．研究室を始め，関 係各位のご協力を謝し結びとする次第である。

$$
\text { 文献 }
$$

(1986)，XV，鹿島出版会.

（2）岡本・ほ加 4 名, 非破壊検查協会年会予稿集，(1988-2), III-II.

（3）宮崎・添か 2 名, 非破壊検查, 30-8 (1977)，546.

（4）甲藤, 伝熱概論, (1979)，385，養賢堂.

（1）日本写真計測学会編, 遠赤外線りモートセンシング技術, 